\title{
Research Group Introduction
}

\section{芝浦工業大学工学部電気工学科 電カシステム研究室}

研究グループ紹介

Power System Laboratory, Department of Electrical Engineering, College of Engineering, Shibaura Institute of Technology

Abstract-Our research has been served for study on control, operation, analysis of power system, which consists 2 D.C., 3 M.C., and 11 B.C. students. At present development of smart grid flexiblization is mainly focused.

\section{1. はじめに}

当研究室は 1998 年にスタートした。当初は芝浦キャンパ スにあったが, 2006 年の新キャンパス設置により豊洲へ移っ ている。

当研究室では電力システムにおける制御, 運用, 解析等を 中心に電力品質の向上, 自然エネルギーの大量導入を目的と した研究を行ってきている。さらには, 発電機制御実験によ る出力安定化, 自動車用バッテリーの長寿命化太陽光発電装 置の研究も行い，二酸化炭素の削減や地球温暖化防止を目指 している。研究内容は電気学会全国大会や $\mathrm{B}$ 部門大会, D 部 門大会, 国際学会等で毎年多くの論文を投稿し，研究業績の 発表を行っている。また，積極的に海外留学生を受け入れて おり国際的な交流を持てる研究室でもある。現在は, 藤田吾 郎准教授のもとに博士課程 2 名, 修士課程 3 名, 学部生 11 名が所属している。これまで約 150 名いる卒業生の進路は, 電力会社, 電気設備会社, 鉄道会社, 電機メーカー, 自動車 メーカーが中心である。

\section{2. 研究テーマ}

現在, 当研究室では「スマートグリッドのフレキシブル化 技術の開発」と題して, スマートグリッドを具現化するため の電力系統設計手法の研究開発を中心に, システム構築上の フレキシビリティ技術に注目して提供することをコアとし ている。近年，スマートグリッドやマイクログリッドといっ た新電力供給システムの研究開発が各所で進んでいる。そし て太陽光発電や風力発電に代表される分散型電源の普及が 期待されている。しかし, 分散型電源が増加すると高調波や 電圧不平衡運転, 瞬時電圧低下といった電力品質の悪化が懸 念され，そのことが導入促進の制約となる。そこで本研究で は, (1)保護継電器整定手法の改良, (2)新しい単独運転検出技 術, (3)共振現象の解明と回避, (4)モジュール型電力系統実習 装置の開発，を課題解決のためのフレキシブル化技術として 位置づけて研究開発を実施している。そして新電力供給シス テムの導入に貢献するとともに, 分散型電源の導入促進も促 して, 低炭素化社会および脱化石燃料社会の実現を目指して いる。

学生は 6 つのグループに分かれている。毎週グループごと のミーティングを行うとともに, 全体での研究成果の報告を
毎週行っている。各グループの研究内容を以下に示す。

<電力品質班>

配電系統の分散型電源普及に伴う保護リレー誤動作の解 析, その対策, 分散型電源普及の課題などの研究, 現地実測 值と数值シミュレーションによる検討などを実施している。

電力会社との共同研究である。

<実験開発班>

新しいスタイルのモジュール形電力系統実習装置の開発 を行い，電力技術者の育成を強化することを目的としてい る。電力関係技術者は, 電力会社・電気設備会社などの業界 から一定のニーズがあり, その育成が大学等に強く求められ ている。それには実体験を伴う電気設備の学習が不可欠であ る。そこで本研究では市販品や既製品にはないメリットを追 求している。複数の外部助成金を原資に活動している。

<分散電源班>

配電系統における新しい単独運転検出方法, 無効電力調整 方法などの研究である。数值シミュレーションによる検討, 実験による補完を目指している。電機メーカーとの共同研究 である。

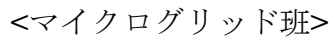

マイクログリッドにおける制御方法などの検討であり, 数 值シミュレーションが中心である。メーカーならびに電気設 備所有事業者志向の研究内容であり, 電機メーカーとの共同 研究である。

$<$ 回転機班>

実習用超小型同期発電機システムの開発，および分散型電 源系統連系用の回転型周波数変換装置について, 数值計算を メインとした検討を実施している。高専との分担実施を行っ ている。

$<$ 自動車班>

自動車の電力マネジメント方式の研究である。数值シミュ レーションによる検討と実験・実測による補完を実施してい る。またサブテーマとしてトラック用太陽光発電装置の長期 評価試験を実施している。自動車研究機関との共同研究であ る。

\section{3. おわりに}

当研究室について簡単ではあるが紹介してきた。今後もさ らなる研究成果をあげるために取り組んでいきたいと考え ている。

藤田吾郎，大川貴宏（芝浦工業大学） (平成 23 年 5 月 6 日受付) 